\title{
INTERNATIONALIZATION OF EDUCATIONAL ACTIVITY OF THE UNIVERSITY IN THE INNOVATIVE LINGVOCULTURAL ENVIRONMENT
}

\author{
S.L. Suvorova, alex97@shadrinsk.net, \\ A.A.Podgorbunskikh, aapodgorbunskikh@mail.ru \\ Shadrinsk State University, Shadrinsk, Russian Federation
}

\begin{abstract}
Nowadays external internationalization of the educational activity of the university is considered as a priority. In Russia, the Export Education Strategy is being developed for the period from 2011 to 2020.

Among all possible directions of the internationalization of the educational activity of the university, the authors consider the modeling of the lingvocultural environment in the university (as a factor of internal internationalization) and international cooperation (as a factor of external internationalization).

The article also considers the internationalization of educational activities in the process of forming the linguistic and cultural competence of students. The authors point out the general segments of the educational and innovative lingvocultural environment of the higher educational institution. The article contains information on software and technical modules and characteristics of the educational environment of the university, as well as the experience of international cooperation of the Shadrinsk State Pedagogical University in the educational sphere.

Keywords: internationalization of educational activity, lingvocultural environment, innovative lingvocultural environment of higher educational establishment, international cooperation.
\end{abstract}

Introduction. Nowadays it is necessary to modernize approaches to the implementation of educational and scientific activities of Russian universities and ensure their competitiveness in the context of globalization as the highest stage of internationalization and integration. An internationalization of the higher education system and integration of an educational space in Europe are the most important trends characterizing the reform of the national higher education systems in developed countries and, consequently, determining the vector of development of modern universities. At the same time, Russian participation in the process of internationalization of higher education, as well as its place on the world market of educational services do not correspond to the available opportunities and the existing needs of Russian universities, so at present Russia is developing a Strategy for the Export of Educational Services of the Russian Federation for the period from 2011 to 2020 .

The internationalization of higher education tends to expand and accelerate, is accompanied by an increase in the homogeneity and continuity of the world educational space, the formation of integrated mega-regional spaces, and the convergence of the properties and parameters of national educational spaces. In the process of internationa- lization, the state and universities are purposefully realizing their own interests, entering into contradictory relations. The main is the contradiction between the financial and regulatory dependence of universities on the state and the desire of universities to autonomy [11, 12, 14, 22]. The introduction of innovative methods and tools for conducting educational, scientific, financial and economic activities in the university becomes a necessary resource to ensure its competitive advantages, realized in transactions in the domestic and foreign markets. It is expedient to evaluate the motives and forms of the internationalization of the activity of the university, which is carried out in the internal and external directions, covering the closely intertwining academic (educational and scientific) and economic components of the university's activity. The internationalization of academic activity stimulates the quality of the service provided by the university under the pressure of competition and thanks to the diffusion of innovation.

Forms of internationalization of the activities of universities are: the convergence of the educational experience of students and the professional experience of teachers from different countries; standardization of programs, unification of credits and diplomas on higher education; export of 


\section{Теория и методика профессионального образования}

educational services and results of scientific activity; mobilization and concentration of foreign funds for the financial provision of statutory activities. The implementation of internationalization implements such strategic goals of the university as improving the quality of education and research, acquiring international recognition and reputation, increasing competitiveness in the national and international markets.

Definitions. The environment of the higher educational institution is an inner factor of the internationalization. Internationalization is a formation of intercultural and international measuring in higher education directed on the improvement of preparation for the specialists' quality [3]. Internationalization as the key aspect of the development of Russian education understood as the process of providing educational services that have an international dimension and what is happening at the national, sectorial and institutional level [15].

The environment of the university is understood as a situation, a circle of factors, conditions, organizational, methodological or psychological measures that facilitate the successful communication between participants in the educational process [4]. And educational environment of the university is viewed from the point of view of various approaches (humanistic, systemic, synergistic, developing education, culturological) in a broad sense as a structure that includes several interrelated levels that are defined administratively, socially, institutionally. It is a systemically organized set of information, technical, educational and methodological support, inextricably linked with man as a subject of the educational process [2, p. 42-47]. Also it is a system of influences and conditions for the formation of a personality according to a given pattern, as well as opportunities for its development contained in the social and spatial-objective environment [8]. Z.I. Tyumaseva understands the educational environment as a set of all educational factors that directly or indirectly affect the person in the mode of education, upbringing and development [7, p. 134].

We share these points of view mentioned above. We believe that it is fundamentally important for the educational environment of the university as professionally active, manageable and dependent on its educational resources. Their quality can be determined by the ability of this environment to provide all subjects of the educational process with a system of opportunities related to meeting their needs and transformation of these needs into life values, which actualizes the process of their personal self-development.

We support the Leontieva's opinion that the ideas of humanization and humanitarization which determine the humanistic nature of professional education, are realized through a certain set of characterological features of the educational environment of the university, the most significant of which are the following [5, p. 106-111]: integrity, including all the necessary components of interaction and forming an integrative space of the university (social, cultural, creative), as well as the integrity of the educational process, revealed in its educational strategy; integrity, which refers to the content of education concentrated in it (knowledge, methods and forms of activity, competence) and acts as its determining factor; multidimensionality (presence and inclusion in the environment of various subprocesses and their interconnection); variability, which determines the filling of the educational environment of the university with a variety of meanings and meanings, the choice of students as content, and forms and methods of auditor and extracurricular activities, which helps to find ways of interaction in other spheres of self-determination; dialogicality, determined by the presence of creative and creative interaction of all subjects of the educational process, and determining subjectivity, openness, universality, corporatism of this interaction.

The linguocultural environment as a subset of the educational environment of the university is a model of the educational space, a systemically organized set of information, technical, educational and methodological support, which is the subject context of the future professional activity of students, which represents the contentobjective basis of teaching languages, linguistic culture and intercultural interaction and provides the learning process Means of access and operation of authentic and educational information that is foreign to other languages, means of computermediated communication in a foreign language, tools for socialization in a foreign culture and remote study of linguistic and cultural realities $[6,10]$.

The linguocultural environment serves as a communicative field in the educational environment of the university, in particular the following:

- ensuring the functioning of a single information and educational space in the process of teaching foreign languages and cultures; 
- maintaining contacts between all participants in the educational environment;

- managing multidimensional information flows in the educational process for training specialists in the field of foreign languages and cultures;

- ensuring the transition to non-linearity, democracy and multidirectional communication between teachers and students;

- ensuring the availability of linguocultural information, the ability to search and select a variety of educational and scientific information relating to foreign language and linguoculture;

- creation of a creative interactive environment for the development of professional (including communicative and linguistic culture) and personal competence of students;

- formation of the personal information culture in the process of virtual interaction.

Since the innovation environment of the university is a set of conditions that provide the prerequisites for the effective formation and development of innovative activity, the innovative linguistic and cultural environment of the university is treated as an innovative model of the educational space, the system of information, quasiprofessional situation.

The international cooperation is an externalfactor of the internationalization. How internationalization and quality assurance can be integrated is a focus on the concept of accreditation and the development of worldwide mutual accreditation networks among institutions as a possible avenue for future progress $[18,21]$. For example we see Japan. Japanese government initiatives the number of foreign students coming to Japan to study and atfacilitating the employment of foreign nationals as members of faculty in Japanese universities. Curricular developments within Japanese universities including undergraduate programs with an international flavor intended for Japanese students and the development of several graduate schools with a focus on international development are detailed [10]. Curricular developments within Japanese universities including undergraduate programs with an international flavor intend for Japanese students and the development of several graduate schools with a focus on international development [20]. Individual institutions have been strongly influenced by these initiatives and some have actively utilized internationalization as a way to enrich their university education [13]. This study revealed that Japanese students and teachers, in contem- plating the perceived meaning of internationalization, are moving towards harmonious coexistence with other national, racial and ethnic groups [17].

Australian higher education offered to students from developing countries, with services delivered to Australian-born students. The process of globalization is contributing to uneven economic and educational development, and may weaken the over-stretched educational systems of poorer countries [19].

Internationalization, viewed as an organizational adaptation, requires its articulation by the leadership while simultaneously institutionalizing a strategic planning process that is representative and participative in that it recognizes and utilizes the power of the culture within which it occurs $[9,16]$.

Recruiting foreign students, creating preparatory faculties, distance learning, expanding the range of additional educational services play an important role in the internationalization of Russian universities. These are an implementation of joint programs on the basis of a foreign university, opening of a foreign branch of a Russian university, promotion abroad of the results of scientific and educational activities, an implementation of projects for the development of teachers abroad. These are also an attraction of foreign grants and scholarships and a participation in international networks and alliances of universities on the basis of consortia [1].

Shadrinsk state pedagogical university over the past 15 years has been carrying out international activities related to internationalization in a number of key areas.

German Academic Exchange Service (DAAD). Annually students and teachers of the university participate in the competition for a scholarship DAAD. Below are the statistics on the number of internships in which teachers and students participated.

Lukinykh N., 2001, Germany, Potsdam;

Lubina L., 2002, Germany, Bamberg;

Aksentyeva E., 2003, Russia, Altai Territory;

Elizova E.I., 2003, Germany, Bielefeld;

Sumina E.S., 2004, Germany, Braunschweig;

Devyatkov S., 2004, Germany, Augsburg;

Ignatieva I., 2004, Germany, Passau;

Solonina L.V., 2005, Germany, Oldenburg;

Zagovenieva A., 2007, Germany, Wittenberg;

Zagovenieva A., 2008, Germany, Wittenberg;

Buinov A., 2008, Germany, Wittenberg;

Bryukhova N., 2008, Germany, Wittenberg;

Sartasova K., 2008, Germany, Wittenberg; 


\section{Теория и методика профессионального образования}

Tumanova O., 2008, Germany, Wittenberg; Pakhotina J., 2008, Germany, Wittenberg; Korotkova E., 2008, Germany, Wittenberg; Sharkunova O., 2008, Germany, Wittenberg; Lovkova E. 2009, Germany, Wittenberg; Peregrimova O., Germany, Wittenberg; Paivina T. 2009, Germany, Wittenberg; Bikmukhametova Yu., 2010, Germany, Wittenberg;

Aksentyeva E.A., 2010, Germany, Munich; Anchugova K., 2011, Germany, Wittenberg; Kondratieva A., 2011, Germany, Wittenberg; Degtyannikova T., 2011, Germany,

Wittenberg;

Sumina E.S., 2011, Germany, Wittenberg; Gubina V., 2011, Germany, Wittenberg; Nemkina A., 2011, Germany, Wittenberg; Kiseleva T., 2012, Germany, Wittenberg; Komarova V., 2012, Germany, Jena; Podgorbunskikh A.A., 2012, Germany, Hamburg;

Filimonova N.V., 2012, Germany, Heidelberg;

Podgorbunskikh A.A., 2012, Austria, Graz; Marchuk M., 2013, Germany, Kassel; Khmeleva N., 2013, Germany, Freiburg; Taushkanova A., 2013, Germany, Bayreuth; Berdnikova K., 2013, Germany, Wittenberg; Balykova K., 2013, Germany, Wittenberg; Sverdlova K., 2013, Germany, Wittenberg; Golubkova A., 2014, Germany, Wittenberg; Kyshtymova E., 2014, Germany, Jena; Semenova A., 2014, Germany, Aachen; Shumilova K., 2014, Germany, Wittenberg; Sycheva A., 2014, Germany, Wittenberg; Neudovnikova G. (PAD), 2014, Germany, Bernburg;

Loginov N. (PAD), 2014, Germany, Jena; Bornovolokova N., 2015, Germany, Jena; Ushakova A., 2015, Germany, Wittenberg; Prokopeva V. (PAD), 2015, Germany, Magdeburg;

Podgorbunskikh A.A., 2015, Germany, Berlin;

Polovnikova A., 2016, Germany, Berlin; Kulish D., 2016, Germany, Hamburg; Meyer B., 2016, Germany, Hamburg; Chepik D., 2016, Germany, Wittenberg; Sycheva A., 2016, Germany, Dusseldorf.

The scientific methodological center of the German methodical literature of J.W. Goethe. The centre has been opened since 2002. Recently, the scope of the activity has been expanded and now the Center's staff is concerned not only with the methodical support of the German teachers at schools and teachers of the universities, but also with the popularization of the German language in the city and the region. The cooperation with the educational institutions of the Federal Republic of Germany and Austria, among other things, develops actively in scientific terms.

Since having been opened, the Center has been supporting contacts and cooperation with the German organizations: the Goethe-Institut and the German Academic Exchange Service (DAAD), and since 2007 - with the University of German Language and Culture M. Luthers (Wittenberg, Germany). Since 2012, the Center has been in contact with the University of Graz (Austria). The Center is actively involved with the regional representation of the German Academic Exchange Service. Every year the representatives of DAAD in the Ural (Mr. Steffen Neumann, Mrs. Kora Maurer, Mr. Alexey Derre) present scientific seminars for students, as well as tests On-DaF, On-set Deutsch).

In the past 3 years the Center has been in contact with the International Cooperation Organization of the City of Tyumen and Center "UniFest travel" (Yekaterinburg), whose representatives Ivan Käfer and Alexander E. Golikow organize annually advisory seminars for students on study abroad. The priority of the activities of the Center has been and remains the implementation of the scientific-methodical seminars for teachers of the German language of the city. In 20154 such workshops were held on the problems of learning the German language at school.

Since 2012 the international webinars have been held annually in the center of Goethe, attended by colleagues from universities in Russia and Germany.

International cooperation with the Republic of Kazakhstan. Within the framework of the international cooperation agreement in January 2017 an internship was organized. The Master student of the Humanities faculty of Shadrinsk state pedagogical university Poluyanova Elena passed the pre-diplomapractice in the Kostanay State Pedagogical Institute.

The purpose of the practice was to test the materials of the master's final qualification work. The student conducted practical exercises, lectures and the training of non-verbal communication, introduced case studies.

Thus internationalization of educational ac- 
tivities is a process in which the goals, functions and organization of the provision of educational services acquire an international dimension. The concept of internationalization in the field of higher education in international practice traditionally includes two aspects: "internalization" at home and "external" internationalization or education abroad, cross-border education.

Internationalization of education includes the following forms of international cooperation:

- individual mobility: mobility of students or faculty for educational purposes;

- mobility of educational programs and institutional mobility;

- formation of new international standards of educational programs;

- integration into the curricula of the international dimension and educational standards;

- institutional partnership: the creation of strategic educational alliances.

To describe the possibilities of internationalization of Russian universities in order to realize the model of the formation of linguocultural competence of students of a pedagogical university. First of all It is necessary to consider the semantic filling of the terms "educational environment of the university", "linguistic culture of the university", and "innovative linguistic culture of the university". And It is important to determine the specifics of these types of environment and common segments that allow to create an innovative linguistic culture environment on the basis of electronic educational resources.

Models. In our opinion, this environment becomes an effective condition for the formation of linguistic and cultural competence of students of the pedagogical university, if it is created on the basis of electronic educational resources, provides synchronous and asynchronous communication of participants in the educational process, testing and administration capabilities, and includes the following software and hardware modules, which include:

- virtual multimedia library of multimedia courses for teaching foreign languages and cultures;

- virtual music library with authentic audio materials on the studied languages;

- a virtual video library containing artistic, documentary, animated films from the countries of the studied language and educational films in DVD format;

- means of access to satellite and local television, based on the technology of streaming video;

- virtual reference system, including multi- lingual dictionaries, multimedia encyclopedias and lexical-grammatical directories;

- computer testing system with multimedia capabilities;

- virtual library of electronic teaching aids and projects;

- virtual library of students' electronic portfolios.

Implications of the models. Thus, by integrating the internal (in the audience, the library) and virtual (in the local or global network) interaction of participants, the distributed learning process allows the implementation of an information training scheme in which it is possible to organize effective independent and research work of students in telecommunication projects and individualize learning.

The teacher organizes cognitive activity of students in the linguistic and cultural environment with the use of heuristic and research, practical and visual methods. For example, introducing individual and group quest projects to find information with specified parameters, publications in a foreign-language Internet zone, electronic communication with the help of a webservices (forum, chat, conference, magazine, e-mail) in the language being studied between teacher and student between students within the academic group or with students from other groups, with external partners in the framework of group research projects.

So, we have examined the peculiarities of the educational and innovative linguistic and cultural environment of the university and came to the conclusion that in order to create the latter there are scientifically grounded opportunities for their segmentation and identification of common components.

We identified the following general segments of the educational and innovative linguistic and cultural environment of the university and determined the possibilities of their optimal composition, taking into account their focus on the preparation of students and their status as subjects of the educational process in universal aspects: the development of educational and professional activities, communication and creativity in the course of intersubject interaction, and the following specific aspects:

- activity (technological): both environments are a "space" of the various activities necessary for the professional training of students;

- informative-methodical. Both mediums include a content area (concepts of professional 


\section{Теория и методика профессионального образования}

training of students in the university, educational and training programs, curricula, textbooks and teaching aids, etc.).

Forms and methods of organization of education (for example, the forms of organization of classes are non-standard types of classes, creative discussions, conferences, etc., research and design form of students' activities, etc. and methods - search, problem, communication, etc.) are:

- spatially-objective: both environments include spatially-objective means, the aggregate of which provides the possibility of the required spatial actions and behavior of the subjects of these kinds of environment;

- social: both environments are a system of interaction of all participants in the educational process;

- communication and organizational: both environments take into account the specific features of the subjects of the educational environment (national characteristics of students and teachers, their values, attitudes, stereotypes, etc.); a communication sphere (subject-subject interaction and social density of subjects of education, etc.); organizational and creative conditions (features of administrative culture, availability of creative groups of students and teachers, etc.).

Conclusion. We believe that the internationalization of educational activities in the university will contribute to the process of forming the linguistic and cultural competence of university students, first of all, in the content-process and evaluation-productive blocks due to the harmonization of the corresponding sub processes. The internationalization of educational activity is optimally revealed in the innovative linguistic and cultural environment of the university at the present stage.

Acknowledgement. Research work is carried out within the framework of the grant № $053 \mathrm{~N}$ "Internationalization of educational activity of the highschool" (Shadrinsk State Pedagogical University).

\section{References}

1. Elkina A.S. Internatsionalizatsiya deyatel'nosti vuzov kak tendentsiya razvitiya sistem vysshego obrazovaniya. Diss. kand. ped. nauk [Internationalization of University Activities as a Trend in the Development of Higher Education Systems. Diss. Cand. (Pedagogy)]. Volgograd, 2010. $201 \mathrm{p}$.

2. Il'chenko O.A. [Standardization of New
Educational Technologies]. Higher Education in Russia, 2006, no. 4, pp. 42-47. (in Russ.)

3. Vazhnichaya E.M., Devyatkina T.A., Devyatkin A.E., Lutsenko R.V., Lugovaya L.A. [Internationalization of Higher Education: General Concepts and some Errors Associated with them]. The World of Medicine and Biology, 2013, no. 2-1 (37), pp. 33-35. (in Russ.)

4. Lashkova L.L. Kontseptsiya razvitiya kommunikativnogo potentsiala budushchikh pedagogov doshkol'nykh obrazovatel'nykh uchrezhdeniy [The Concept of Development of the Communicative Potential of Future Teachers of Preschool Educational Institutions]. Chelyabinsk, South Ural State Univ. Publ., 2011. 391 p.

5. Leont'eva O.V. [Cultural-educational Environment of the University as a Psychological-pedagogical Problem]. Education and Society, 2009, no. 6 (59), pp. 106-111. (in Russ.)

6. Tumalev A.V. [The Role of the Virtual Environment in the Development of the Professional Competence of a Specialist]. Global'nyy ekonomicheskiy krizis: realii i puti preodoleniya: sbornik nauchnykh statey [The Global Economic Crisis: Realities and Ways to Overcome: a Collection of Scientific Articles]. St. Petersburg, 2009, pp. 515-521. (in Russ.)

7. Tyumaseva Z.I. Sistemnoe obrazovanie $i$ obrazovatel'nye sistemy [System Education and Educational Systems]. Chelyabinsk, ChGPU Publ., 1999. 280 p.

8. Yasvin V.A. Obrazovatel'naya sreda: ot modelirovaniya $k$ proektirovaniyu [Educational Environment: from Modeling to Design]. Moscow, Smysl Publ., 2001. 365 p.

9. Bartell M. Internationalization of Universities: a University Culture-based Framework. Higher Education, 2003, vol. 45, no. 1, pp. 43-70. DOI: $10.1023 / \mathrm{A}: 1021225514599$

10. Byram M. Assessing Intercultural Competence in Language Teaching. Sprogforum, 2004 , vol. 6 , no. 18 , pp. 8-13.

11. De Wit H. Internationalization of Higher Education in the United States of America and Europe: A Historical, Comparative and Conceptual Analysis. Westport, Greenwood Press Publ., 2002.

12. Enders J. Higher Education, Internationalization and the Nation State: Recent Developments and Challenges to Governance Theory. Higher Education, 2004, no. 47 (3), pp. 361-382. DOI: 10.1023/B:HIGH.0000016461.98676.30

13. Horie $M$. The Internationalization of Higher Education in Japan in the 1990s: a Recon- 
sideration. Higher Education, 2002, vol. 43, no. 1, pp. 65-84. DOI: 10.1023/A:1012920215615

14. Knight J. Internationalization Remodeled: Definition, Approaches and Rationales. Journal of Studies in Intercultural Education, 2004, no. 8 (1), pp. 5-31. DOI: 10.1177/1028315303260832

15. Lysenko E. Internationalization as a Key Aspect of Development of High Education. European Review of Social Sciences, 2015, vol.2, no. 1, pp. 41-46.

16. Schoorman D. What Really do we Mean by "Internationalization?" Contemporary Education, 2000, vol. 71, no. 4, pp. 5-11.

17. Shew M.T. Internationalization in Schools in Japan: Educator's and Students' Perceptions of Efforts toward Internationalization and Students' Intercultural Awareness. Boston, Boston University Publ., 2000.

18. Tice T.N. Internationalization. Educa tion Digest, 1991, vol. 56, no. 6, pp. 48-49.

19. Turpin T., Iredale R., Crinnion P. The Internationalization of Higher Education: Implications for Australia and its Education "Clients". Minerva, 2002, vol. 40, no. 4, pp. 327-340. DOI: 10.1023/A:1020933923270

20. Umakoshi T. Internationalization of Japanese Higher Education in the 1980's and Early 1990's. Higher Education, 1997, vol. 34, no. 2, pp. 259-273. DOI: 10.1023/A:1003049301267

21. Van Damme D. Internationalization and Quality Assurance: towards Worldwide Accreditation? European Journal for Education Law and Policy, 2000, vol. 4, no. 1, pp. 1-20. DOI: 10.1023/A:1003049301267

22. Yang R. [University Internationalization: Its Meanings, Rationales and Implications]. Intercultural Education, 2002, no. 13 (1), pp. 89-95. DOI: 10.1080/14675980120112968

Received 1 December 2016

\title{
ИНТЕРНАЦИОНАЛИЗАЦИЯ ОБРАЗОВАТЕЛЬНОЙ ДЕЯТЕЛЬНОСТИ УНИВЕРСИТЕТА В ИННОВАЦИОННОЙ ЛИНГВОКУЛЬТУРНОЙ СРЕДЕ
}

\author{
С.Л. Суворова, А.А. Подгорбунских \\ Шадринский государственный педагогический университет, г. Шадринск
}

\begin{abstract}
В настоящее время внешняя интернационализация образовательной деятельности вуза рассматривается как приоритетное направление. В России осуществляется разработка Стратегии экспорта образовательных услуг на период с 2011 по 2020 г.

Среди всех возможных направлений интернационализации образовательной деятельности вуза авторы статьи рассматривают моделирование лингвокультурной среды в вузе (как фактор внутренней интернационализации) и международное сотрудничество (как фактор внешней интернационализации).

В статье также рассматривается интернационализация образовательной деятельности в процессе формирования лингвокультурной компетенции студентов. Авторы указывают на общие сегменты образовательной и инновационной лингвокультурной среды в высшем учебном заведении. В статье изложена информация о программно-технических модулях и характеристиках образовательной среды вуза, а также представлен опыт международного сотрудничества Шадринского государственного педагогического университета в образовательной сфере.

Ключевые слова: интернационализация образовательной деятельности, лингвокультурная среда, инновационная лингвокультурная среда вуза, международное сотрудничество.
\end{abstract}

Исследовательская работа выполнена в рамках гранта № 053Н «Интернационализация образовательной деятельности вуза» (Шадринский государственный педагогический университет). 


\section{Теория и методика профессионального образования}

\section{Литература}

1. Елкина, А.С. Интернационализачии деятельности вузов как тенденции развития систем высшего образования: дис. ... канд. эконом. наук / А.С. Елкина. - Волгоград, 2010. - 201 с.

2. Ильченко, О.А. Стандартизачия новых образовательных технологий / О.А. Ильченко // Высшее образование в России. - 2006. - № 4. - С. 42-47.

3. Интернационализаџия высшего образования: общие концепџии и некоторые заблуждения с ними связанные / Е.М. Важничая, Т.А. Девяткина, А.Е. Девяткин и др. // Світ медищини та біологіi. - 2013. - № 2-1 (37). - С. 033-035.

4. Лашкова, Л.Л. Концепиия развития коммуникативного потенциала будущих педагогов дошкольных образовательных учреждений / Л.Л. Лашкова. - Челябинск: Издат. центр ЮУрГУ, 2011. $-391 \mathrm{c}$.

5. Леонтьева, О.В. Культурно-образовательная среда вуза как психолого-педагогическая проблема / О.В. Леонтьева // Образование и общество. - 2009. - № 6 (59). - С. 106-111.

6. Тумалев, А.В. Роль виртуальной среды в развитии профессиональной компетентности спечиалиста / А.В. Тумалев // Глобальный экономический кризис: реалии и пути преодоления: сб. науч. cm. - СПб.: Ин-т бизнеса и права, 2009. - C. 515-521. - http://www.ibl.ru/konf/031209/118.html.

7. Тюмасева, 3.И. Системное образование и образовательные системы: моногр. / З.И. Тюмасева. - Челябинск: Изд-во ЧГПУ, 1999. - 280 с.

8. Ясвин, В.А. Образовательная среда: от моделирования к проектированию / В.А. Ясвин. М.: Изд-во «Смыслл», 2001. - 365 c.

9. Bartell, M. Internationalization of universities: a university culture-based framework / M. Bartell // Higher Education. - 2003. - T. 45. № 1. - P. 43-70.

10. Byram, M. Assessing Intercultural Competence in Language Teaching / M. Byram // Sprogforum. - 2004. - № 18, Vol. 6. - P. 8-13.

11. De Wit, H. Internationalization of higher education in the United States of America and Europe: A historical, comparative and conceptual analysis / H. De Wit. - Westport, CT: Greenwood Press, 2002.

12. Enders, J. Higher education, internationalization and the nation state: Recent developments and challenges to governance theory / J. Enders // Higher Education. - 2004. - № 47(3). - P. 361-382.

13. Horie, M. The internationalization of higher education in Japan in the 1990s: a reconsideration / M. Horie // Higher Education. - 2002. - T. 43. № 1. - P. 65-84.

14. Knight, J. Internationalization remodeled: Definition, approaches and rationales / J. Knight // Journal of Studies in Intercultural Education. - 2004. - № 8(1). - P. 5-31.

15. Lysenko, E. Internationalization as a key aspect of development of high education / E. Lysenko // Европейское обозрение общественных наук. - 2015. - T. 2, № 1. - P. 41-46.

16. Schoorman, D. What really do we mean by "internationalization?" / D. Schoorman // Contemporary Education. - 2000. - T. 71, № 4. - P. 5-11.

17. Shew, M.T. Internationalization in schools in Japan: educator's and students' perceptions of efforts toward internationalization and students' intercultural awareness / M.T. Shew. - Boston: Boston University Publ., 2000.

18. Tice, T.N. Internationalization. Education Digest / T.N. Tice. - 1991. - T. 56, № 6. - P. 48-49.

19. Turpin, T. The internationalization of higher education: implications for Australia and its education "clients"/ T. Turpin, R. Iredale, P. Crinnion // Minerva. - 2002. - T. 40, № 4. - P. 327-340.

20. Umakoshi, T. Internationalization of Japanese higher education in the 1980's and early 1990's // Higher Education. - 1997. - T. 34, № 2. - P. 259-273.

21. Van Damme, D. Internationalization and quality assurance: towards worldwide accreditation? / D. van Damme // European Journal for Education Law and Policy. - 2000. - T. 4, № 1. P. 1-20.

22. Yang, R. University internationalization: Its meanings, rationales and implications / R. Yang // Intercultural Education. - 2002. - № 13(1). - P. 89-95. 
Суворова Светлана Леонидовна, доктор педагогических наук, профессор, и.о. заведующего кафедрой славяно-германской филологии, Шадринский государственный педагогический университет, г. Шадринск, alex97@shadrinsk.net.

Подгорбунских Анастасия Александровна, кандидат педагогических наук, доцент, зам. начальника управления образовательной политики, Шадринский государственный педагогический университет, г. Шадринск, aapodgorbunskikh@mail.ru.

Поступила в редакцию 1 декабря 2016 2.

\section{ОБРАЗЕЦ ЦИТИРОВАНИЯ}

Suvorova, S.L. Internationalization of Educational Activity of the University in the Innovative Lingvocultural Environment / S.L. Suvorova, A.A. Podgorbunskikh // Вестник ЮУрГУ. Серия «Образование. Педагогические науки». - 2017. - Т. 9, № 2. - С. 53-61. DOI: $10.14529 /$ ped 170205

\section{FOR CITATION}

Suvorova S.L., Podgorbunskikh A.A. Internationalization of Educational Activity of the University in the Innovative Lingvocultural Environment. Bulletin of the South Ural State University. Ser. Education. Educational Sciences. 2017, vol. 9, no. 2, pp. 53-61. DOI: $10.14529 /$ ped 170205 